\title{
ANALISA RESPON MEKANIK GENTENG KOMPOSIT CONCRETE FOAM DIPERKUAT SERAT TANDAN KOSONG KELAPA SAWIT (TKKS) AKIBAT BEBAN IMPAK JATUH BEBAS
}

\author{
Suwandy Winata ${ }^{1}$, Bustami Syam ${ }^{2}$, M. Sabri ${ }^{3}$, Marragi M. ${ }^{4}$, Alfian Hamsi ${ }^{5}$ \\ 1,2,3,4,5 Departemen Teknik Mesin, Fakultas Teknik, Universitas Sumatera Utara \\ E-mail : suwandy91@gmail.com
}

\begin{abstract}
ABSTRAK
Perkembangan industri kelapa sawit dewasa ini semakin pesat. Salah satu hasil industri kelapa sawit yang kerap menjadi limbah adalah Tandan Kosong Kelapa Sawit (TKKS). TKKS ini dapat diolah menjadi serat yang akhirnya dapat dimanfaatkan sebagai material engineering. Tujuan penelitian ini adalah untuk menganalisa mutu fisik dan respon mekanik yang diterima genteng komposit dan genteng komersil akibat beban impak jatuh bebas. Spesmen yang akan di uji berukuran $380 \times 235 \times$ $20 \mathrm{~mm}$. kekuatan mekanik material diperoleh dengan cara melakukan pengujian yaitu menggunakan alat uji impak jatuh bebas. Dari hasil analisa mutu fisik, berat genteng dapat direduksi hingga 44,89\% dan memiliki berat rata-rata $1,518 \mathrm{~kg}$, rata-rata area porositas pada genteng komposit adalah $55,85 \%$, dan hasil uji rembesan air tidak ditemukan adanya kerusakan struktur dan rembesan air, namun penyerapan air hingga $62 \%$. Pada pengujian impak jatuh bebas diperoleh gaya impak yang diterima genteng komposit pada ketinggian 0,5 m dan $1 \mathrm{~m}$ adalah 106,0461 $\mathrm{N}$ dan 132,5331 N. Sedangkan pada genteng komersil dengan ketinggian yang sama diperoleh 150,2892 N dan 167,9472 N. Pola kerusakan yang terjadi pada genteng komposit adalah patah matriks namun belum mengalami kegagalan pada serat, sedangkan pada genteng komersil mengalami patah matriks dan terpisah menjadi beberapa bagian. Perbedaan pola kerusakan ini disebabkan karena genteng komposit memiliki struktur yang berbusa dan memiliki penguat serat yang meredam tegangan yang masuk pada specimen dan membuat sifat genteng menjadi kurang getas daripada genteng komersil.

Kata kunci : Limbah Tandan Kosong Kelapa Sawit, Material Engineering, Concrete Foam, Beban Impak Jatuh Bebas, Genteng Komposit.
\end{abstract}

\section{PENDAHULUAN}

Genteng sudah sangat umum digunakan di berbagai belahan dunia sebagai pelindung bagian dalam bangunan dari pengaruh cuaca. Diperkirakan genteng sudah digunakan dalam konstruksi bangunan sejak 3000-an tahun sebelum masehi. Genteng tidak hanya berfungsi melindungi bagian dalam bangunan dari hujan dan panas, genteng juga harus mampu menahan beban flexure dan dinamik. Selain itu genteng juga harus mampu meredam kebisingan yang ditimbulkan akibat rain drop, tidak mudah terdeformasi akibat perubahan suhu, serta memiliki bobot yang tidak terlalu berat..

Tandan kosong kelapa sawit (TKKS) merupakan salah satu limbah terbesar yang dihasilkan dari pengolahan kelapa sawit. TKKS yang dihasilkan dapat mencapai $230 \mathrm{~kg}$ per 1 ton pengolahan tandan buah segar [1].

Beton memiliki sifat getas yang tidak menguntungkan, yang membuat beton langsung rusak jika dikenai tegangan impak [2]. Batako ringan dari bahan concrete foam yang diperkuat serat TKKS memiliki modulus elastisitas 5,82 GPa jauh lebih mampu menyerap tegangan impak dibandingkan batako ringan di pasaran [3]. Penulis akan mencoba proses pembuatan genteng komposit dengan menggunakan bahan concrete foam yang diperkuat oleh serat TKKS.

1. Batasan Masalah 
Pembuatan genteng komposit menggunakan busa dengan memanfaatkan foam generator untuk membuat busa secara terpisah. Setelah busa terbentuk baru dimasukkan ke dalam adonan beton dan selanjutnya ke dalam cetakan.

2. Tujuan Penelitian

Dari uraian latar belakang dan rumusan masalah pada pendahuluan maka tujuan umum dari penelitian ini adalah untuk membandingkan ketahanan genteng komposit berbahan concrete foam yang diperkuat serat TKKS dengan genteng komersil terhadap impak dengan metode impak jatuh bebas secara eksperimental.

3. Manfaat Penelitian

Manfaat penelitian ini adalah untuk memberikan masukan kepada dunia pendidikan dan dunia industri tentang produk genteng komposit dari material concrete foam yang diperkuat serat TKKS secara fisis dan mekanis. Selain itu juga untuk memanfaatkan limbah TKKS menjadi sebuah produk yang memiliki nilai guna yang lebih tinggi.

\section{TINJAUAN PUSTAKA \\ Bahan Komposit}

Komposit adalah campuran dua material atau lebih yang dicampur secara makroskopik untuk menghasilkan suatu material baru. Artinya penggabungan sifat-sifat unggul dari pembentuk material masih terlihat nyata [3].

\section{Genteng Beton}

Genteng beton atau genteng semen adalah unsur bangunan yang dipergunakan untuk atap yang dibuat dari beton dan dibentuk sedemikian rupa serta berukuran tertentu, dibuat dengan cara mencampur pasir dan semen ditambah dengan air, kemudian diaduk sampai homogen lalu dicetak, selain semen dan pasir, sebagai bahan pembuatan genteng beton dapat juga ditambahkan kapur

\section{Material Komposit Concrete Foam}

Pada komposit concrete foam, materialnya terdiri dari semen, pasir, air, blowing agent dan serat TKKS. Blowing agent yang digunakan dalam penelitian ini adalah surfaktan.

\section{Gerak Lurus}

Perpindahan adalah sebuah perubahan kedudukan ini merupakan besaran vektor yang memiliki jarak dan arah. Percepatan dapat didefinisikan sebagai laju perubahan kedudukan terhadap waktu. Ini juga merupakan besaran vektor yang memiliki jarak, arah, dan waktu.

$$
V=\sqrt{2 g \cdot h}
$$

dimana:

$\mathrm{v}=$ Kecepatan benda jatuh bebas, $(\mathrm{m} / \mathrm{s})$.

$\mathrm{g}=$ Gaya grafitasi, $\left(\mathrm{m} / \mathrm{s}^{2}\right)$.

$\mathrm{h}=$ ketinggian jatuh benda, $(\mathrm{m})$.

\section{Momentum dan Impuls}


Momentum dan Impuls adalah sebagai satu kesatuan karena momentum dan Impuls dua besaran yang setara. Dua besaran dikatakan setara seperti momentum dan Impuls bila memiliki satuan Sistem Internasional (SI) sama atau juga dimensi sama.

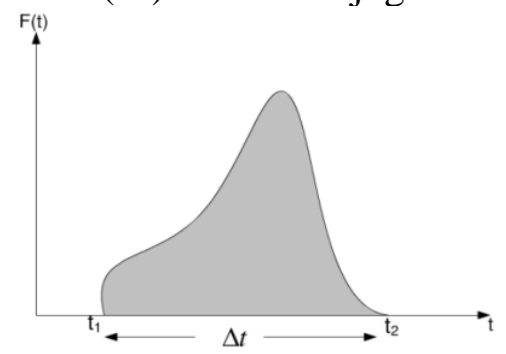

Gambar 2.1 Grafik gaya vs waktu

$$
M=m \cdot v
$$

dimana:

$\mathrm{M}=$ momentum, $(\mathrm{kg} \cdot \mathrm{m} / \mathrm{s})$.

$\mathrm{m}=$ massa, $(\mathrm{kg})$.

$\mathrm{v}=$ kecepatan, $\left(\mathrm{ms}^{-2}\right)$.

Impuls adalah lonjakan gaya tiba-tiba pada selang waktu tertentu yang merupakan hasil kali gaya dengan selang waktu yang diperlukan. Grafik implus dideskripsikan seperti pada gambar 2.1, dan dapat dinyatakan dalam persamaan (2.3).

$$
I=F . t
$$

Dimana:

$\mathrm{I}=$ implus

$\mathrm{F}=\operatorname{gaya}(\mathrm{N})$

$\mathrm{t}=$ waktu $(\mathrm{s})$

\section{Tegangan}

Besarnya tegangan menunjukkan apakah bahan tersebut mampu menahan perubahan bentuk sebelum patah. Makin besar tegangan suatu bahan maka bahan itu mudah dibentuk. Maka, rumus tegangan adalah:

$$
\sigma=\frac{\mathrm{F}}{\mathrm{Ao}}
$$

Dimana:

$\sigma=$ Tegangan $\left(\mathrm{N} / \mathrm{m}^{2}\right)$

$\mathrm{F}$ = gaya (Newton)

$\mathrm{A}_{\mathrm{o}}=$ luas penampang awal $\left(\mathrm{m}^{2}\right)$

\section{Porositas}

Porositas adalah besarnya persentase ruang- ruang kosong atau besarnya kadar pori yang terdapat pada beton dan merupakan salah satu faktor utama yang mempengaruhi kekuatan beton. Pori-pori beton biasanya berisi udara atau berisi air yang saling berhubungan dan dinamakan dengan kapiler beton. Kapiler beton akan tetap ada walaupun air yang digunakan telah menguap, sehingga kapiler ini akan mengurangi kepadatan beton yang dihasilkan. Dengan bertambahnya volume pori maka nilai porositas juga akan semakin meningkat dan hal ini memberikan pengaruh buruk terhadap kekuatan beton [11]. 


\section{METODOLOGI PENELITIAN}

Tempat dan Waktu

Penelitian ini dilaksanakan dalam beberapa tahapan, yaitu seperti diuraikan pada Tabel 3.1.

\begin{tabular}{|c|c|c|}
\hline No. & Aktifitas & Lokasi Penelitian \\
\hline 1. & $\begin{array}{l}\text { Pembuatan } \\
\text { serat TKKS }\end{array}$ & $\begin{array}{l}\text { Pusat Riset IMPak } \\
\text { dan Keretakan, Dept. } \\
\text { Teknik Mesin, FT- } \\
\text { USU. }\end{array}$ \\
\hline 2. & $\begin{array}{l}\text { Pembuatan } \\
\text { genteng } \\
\text { komposit } \\
\text { dicampur } \\
\text { serat } T K K S\end{array}$ & $\begin{array}{l}\text { Pusat Riset IMPak } \\
\text { dan Keretakan, Dept. } \\
\text { Teknik Mesin, FT- } \\
\text { USU. }\end{array}$ \\
\hline 3. & $\begin{array}{l}\text { Uji impak } \\
\text { jatuh bebas }\end{array}$ & $\begin{array}{l}\text { Pusat Riset IMPak } \\
\text { dan Keretakan, Dept. } \\
\text { Teknik Mesin, FT- } \\
\text { USU. }\end{array}$ \\
\hline
\end{tabular}

4. Analisa data olah data

\footnotetext{
Alat dan Bahan

Beberapa alat yang digunakan dalam penelitian ini adalah sebagai berikut:

1. Alat uji impak jatuh bebas

2. Horizontal shaft mixer

3. Foam generator

4. Timbangan digital

5. Wadah adukan

6. Mesin penghalus serat

7. Cetakan

8. Gelas ukur

Bahan-bahan yang akan digunakan dalam penelitian ini adalah:

1. Pasir

2. Semen

3. Air bersih

4. Foaming agent

5. Serat TKKS
}

\section{Geometri Spesimen}

Geometri spesimen akan diuji impak jatuh bebas seperti ditunjukkan pada Gambar 3.1.

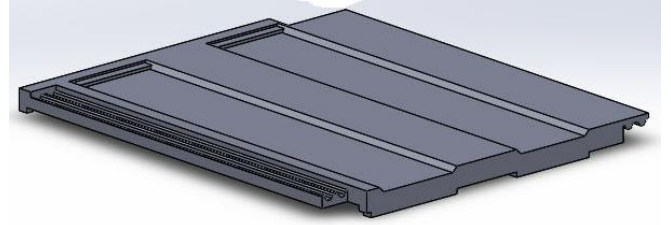

Proses Pembuatan Genteng Komposit

Gambar 3.1 Geometri spesimen genteng 


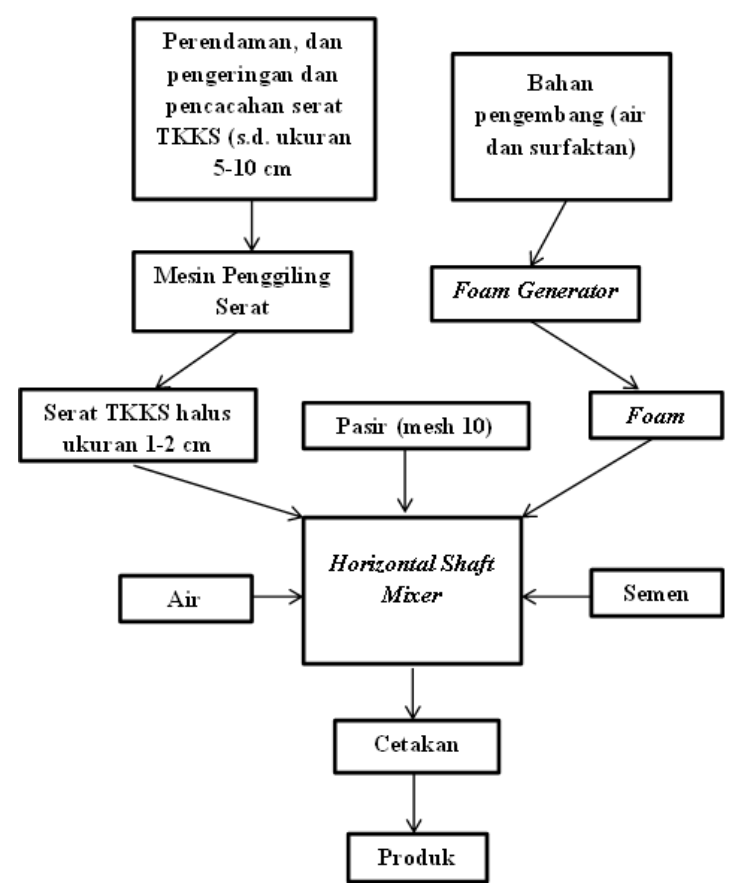

Gambar 3.2 Diagram alir proses pembuatan genteng komposit

\section{Alat Cetak Genteng Komposit}

Alat cetakan terbuat dari fiberglass dengan ukuran $380 \times 235 \times 20 \mathrm{~mm}$ seperti diperlihatkan pada Gambar 3.3.

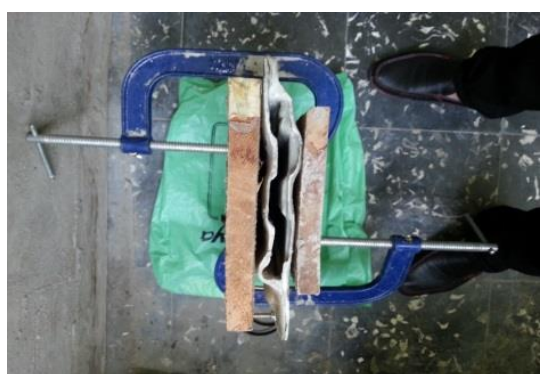

Gambar 3.3 Alat cetak genteng komposit

\section{Analisa Hasil Produk}

1. Reduksi Berat

Prosedur pengukuran:

1. Ambil 5 buah sampel masing-masing genteng komposit dan genteng komersil.

2. Timbang sampel dan catat hasilnya.

\section{Makrostruktur}

Prosedur pengukuran menggunakan software ImageJ untuk mendapatkan jumlah dan besar butir udara adalah sebagai berikut:

1. Klik start menu dan pilih ImageJ

2. Klik File $\rightarrow$ Open $\rightarrow$ Pilih gambar yang sudah dipotong dengan software Adobe Photoshop.

3. Klik icon Line dan buatlah garis secara horizontal dari sisi kiri ke sisi kanan. 
4. Klik Analyze $\rightarrow$ Set Scale $\rightarrow$ Known distance $=10 \rightarrow$ Unit of length adalah $\mathrm{mm} \rightarrow \mathrm{OK}$.

5. Klik Image $\rightarrow$ Adjust $\rightarrow$ Treshold $\rightarrow$ Treshold color $\mathrm{B} \& \mathrm{~W} \rightarrow$ Close window.

6. Klik Analyze $\rightarrow$ Analyze particles $\rightarrow$ Pada Show pilih Outlines $\rightarrow$ Centang Display result $\rightarrow$ OK.

7. Simpan file dalam format Ms. Excel.

3. Uji Rembesan Air

Pengujian kemampuan kedap air pada genteng pada penelitian ini mengacu pada standar SNI0096-2007 dengan skema set-up uji seperti diperlihatkan pada Gambar 3.3 [10].

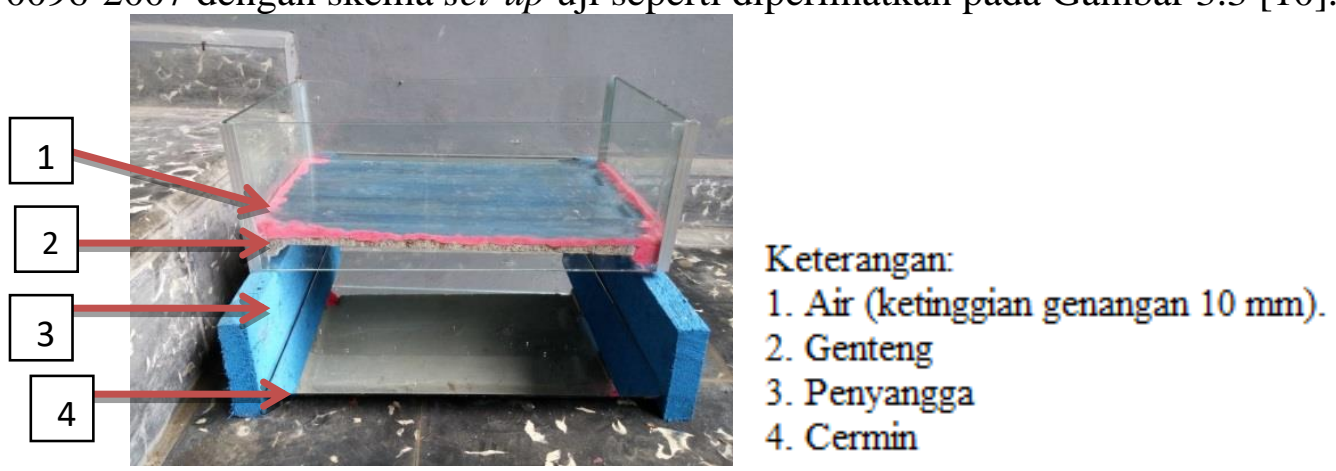

Gambar 3.3 Set-up uji rembesan air

Langkah-langkah pengujian permeabilitas genteng adalah sebagai berikut:

1. Siapkan genteng komposit sebanyak 3 buah.

2. Letakkan genteng pada penyangga.

3. Lapisi sekeliling benda uji dengan pasta penambal (seal).

4. Tuang air keatas genteng hingga ketinggian $15 \mathrm{~mm}$.

5. Biarkan selama 20 jam \pm 5 menit dalam suhu ruangan $30^{\circ} \mathrm{C}$ dan kelembaban relatif $40 \%$.

6. Catat ada atau tidak adanya tetesan air yang jatuh pada permukaan cermin.

\section{Setup Pengujian}

Metode pengujian impak jatuh bebas yang akan digunakan adalah drop weight. Gambar setup seperti ditunjukkan pada gambar 3.4.

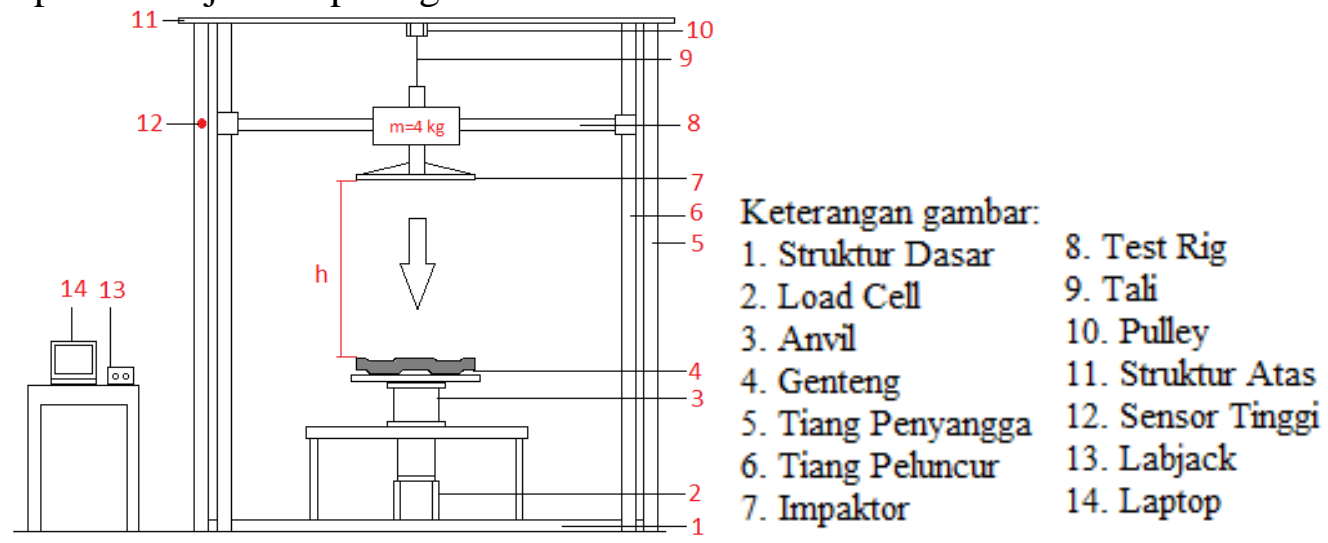

Gambar 3.4. Setup pengujian

\section{Prosedur Pengujian}

Sebelum dilakukan pengujian terlebih dahulu dilakukan persiapan terhadap specimen yaitu: 
1. Letakkan impaktor yang berbentuk plat datar berukuran $385 \times 235 \mathrm{~mm}$ diatas permukaan genteng yang akan diuji.

2. Amati apakah ada ruang kosong pada permukaan yang seharusnya bersentuhan.

3. Jika ada ruang kosong, maka cari bagian yang tidak rata dan lakukan pengamplasan atau dikikir permukaan yang tidak rata tersebut hingga permukaan plat dapat bersentuhan dengan area impak yang diinginkan.

Langkah-langkah pengujian:

1. Letakkan sampel uji yang akan dilakukan pengujian diatas anvil.

2. Pada permukaan plat impaktor yang akan bersentuhan dengan genteng di lapisi dengan cat warna biru.

3. Tentukan posisi jarak ketinggian jatuh impaktor yang diinginkan, dan pastikan sensor proximity dalam kondisi aktif.

4. Tekan tombol Start pada software DAQfor Helmet Impact Testing.

5. Setelah jarak ketinggian ditentukan dan memastikan bahwa sensor proximity sudah berfungsi, specimen uji dan test rig sudah terpasang, maka impaktor siap untuk dijatuhkan dengan cara melepas tali penahan luncuran impaktor.

6. Tekan tombol STOP setelah beberapa saat impaktor menumbuk specimen pada anvil.

7. Tekan tombol $S A V E$ untuk menyimpan data hasil uji ke dalam file berformat txt, dan akan tersimpan dalam drive $\mathrm{C}$ folder DATAEXP (data experiment).

8. Lalu data hasil pengujian tersebut kita olah dengan menggunakan program software $M S$ EXCEL.

\section{Diagram Alir Penelitian}

Diagram alir penelitian ditunjukkan pada Gambar 3.5. 


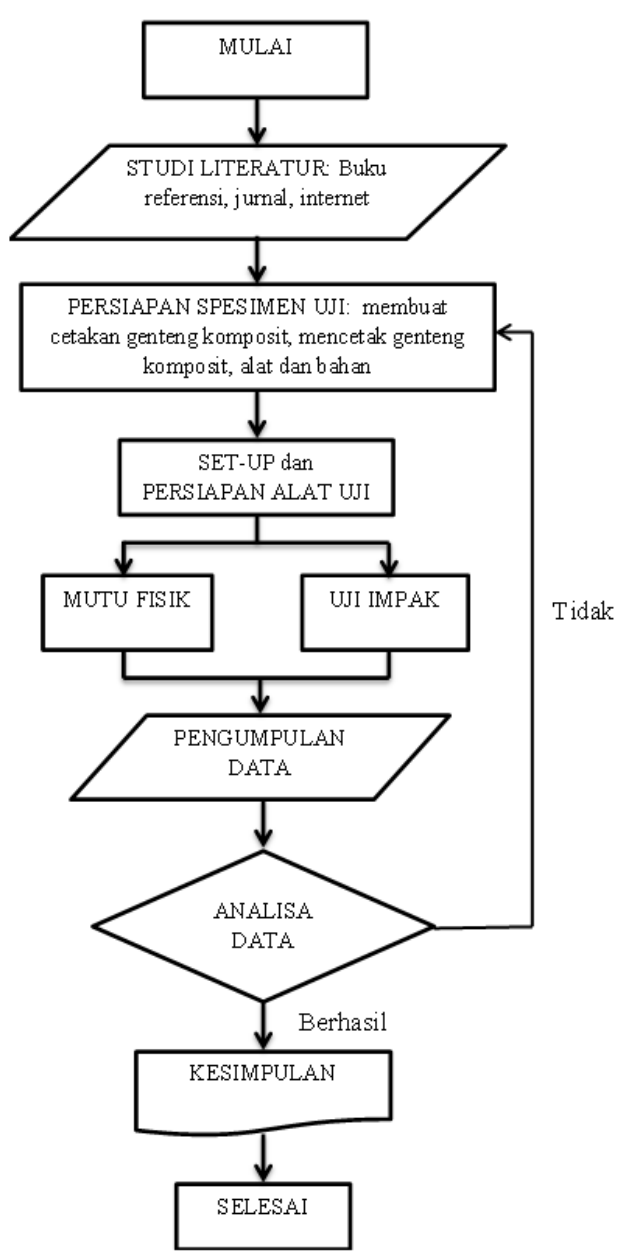

Gambar 3.5 Diagram alir penelitian

\section{Hasil dan Pembahasan}

Hasil pembuatan genteng komposit.

Genteng komposit yang dicetak mempunyai ukuran $380 \times 235 \times 20 \mathrm{~mm}$ dapat dilihat pada gambar 4.1.

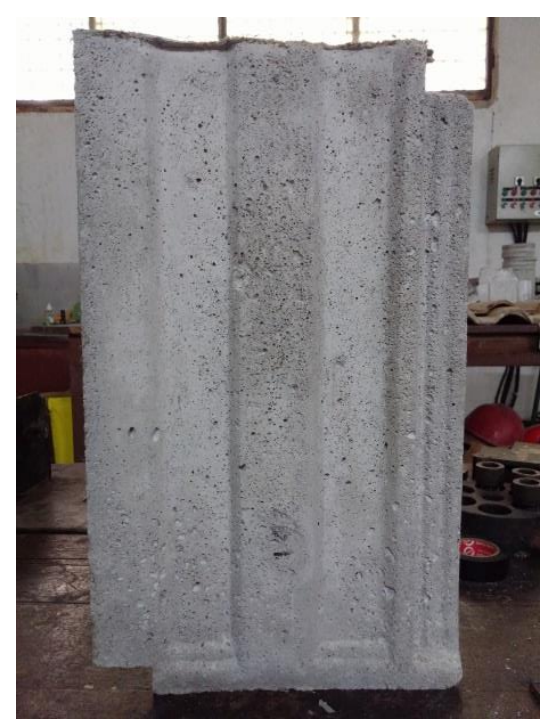

Gambar 4.1 Hasil cetakan 


\section{Analisa Hasil Produk}

1. Reduksi Berat

Berat genteng komposit berbahan concrete foam diperkuat serat TKKS berhasil direduksi hingga $44,89 \%$. Dan memiliki berat rata-rata $1,518 \mathrm{~kg}$.

2. Makrostruktur

Hasil produk genteng concrete foam yang dianalisa makrostruktur permukaannya menggunakan aplikasi ImageJ dapat dilihat pada Gambar 4.2.

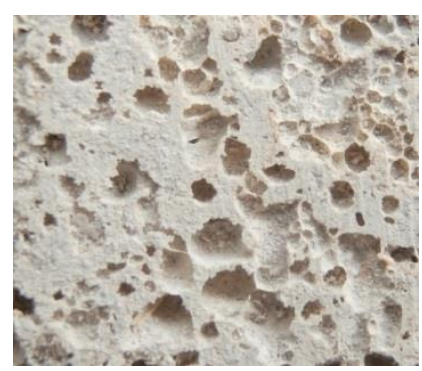

(a)

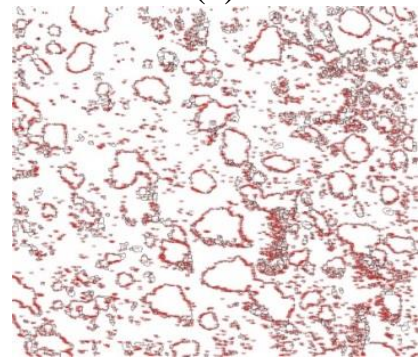

(b)

Gambar 4.2 (a) Foto makrostruktur permukaan, (b) Foto hasil analisa makrostruktur

Berdasarkan hasil analisa makrostruktur bagian permukaan genteng komposit yang ditunjukkan pada Gambar 4.2 (b), ditemukan 18 titik porositas yang ditunjukkan dengan lingkaran merah dengan area $49,42 \%$ per $100 \mathrm{~mm}^{2}$ penampang permukaan dan besar porositas yang dapat diterima rata-rata $0,008 \mathrm{~mm}^{2}$.

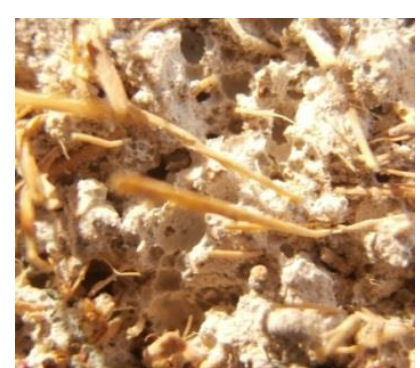

(a) 


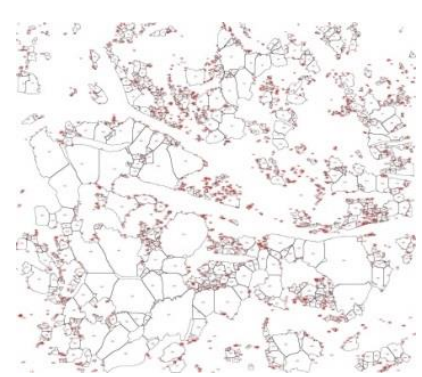

(b)

Gambar 4.3 (a) Foto makrostruktur bagian dalam, (b) Foto hasil makrostruktur

Berdasarkan hasil analisa makrostruktur bagian dalam genteng komposit yang ditunjukkan pada Gambar 4.3 (b), ditemukan 40 titik porositas yang ditunjukkan dengan lingkaran merah dengan area $62,3 \%$ per $100 \mathrm{~mm}^{2}$ penampang permukaan dan besar porositas rata-rata yang dapat diterima adalah $0,013 \mathrm{~mm}^{2}$.

Rata-rata area porositas pada spesimen genteng komposit dapat dilihat pada Tabel 4.2.

Tabel 4.2 Area porositas

\begin{tabular}{cc}
\hline Penampang & Area Porositas (\%) \\
\hline Permukaan & 49,42 \\
Bagian dalam & 62,3 \\
\hline Rata-Rata & $\mathbf{5 5 , 8 6}$ \\
\hline
\end{tabular}

Perbedaan porositas bagian dalam dan bagian permukaan cukup besar, hal ini disebabkan pada bagian dalamterdapat lebih banyak butir-butir udara yang berasal dari foam, selain itu juga disebabkan oleh air yang menempati ruang kosong pada saat dicetak. Air yang telah menguap pada masa pengeringan kemudian meninggalkan porositas pada bagian dalam spesimen.

\section{Hasil Uji Rembesan air}

Dari hasil uji permeabilitas genteng dengan jumlah sampel sebanyak 3 buah yang sudah dilapisi dengan cat beton, diperoleh bahwa genteng dari bahan komposit concrete foam diperkuat serat TKKS mampu menahan kuantitas air selama 20 jam \pm 5 menit tanpa adanya kerusakan struktur dan rembesan air.. Tidak ditemukan tetesan air namun genteng menjadi lembab akibat penyerapan air.

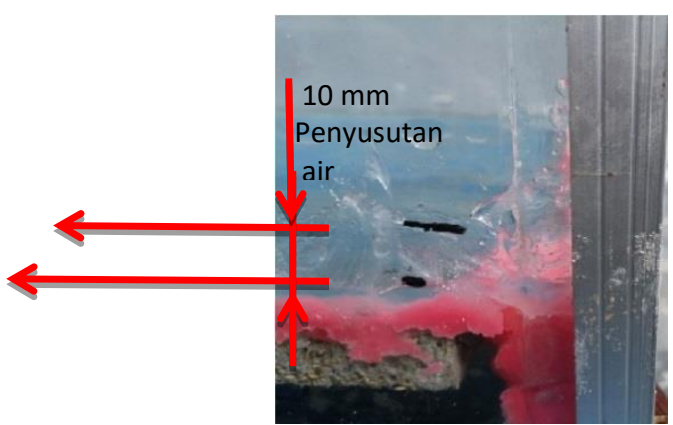

Gambar 4.4 Batas air setelah 20 jam 


\section{Hasil Uji Impak Jatuh Bebas}

1. Ketinggian $0,5 \mathrm{~m}$

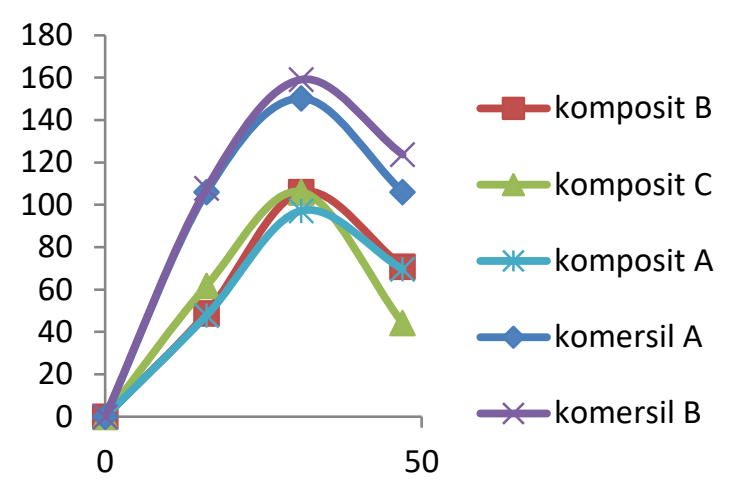

Gambar 4.5 Grafik gaya impak ketinggian jatuh 0,5 m.

Dari Gambar 4.5 dapat dilihat bahwa untuk katerori gaya impak ketinggian 0,5 $\mathrm{m}$ untuk genteng komposit diperoleh gaya impak spesimen komposit $\mathrm{A}=97,2171 \mathrm{~N}$, spesimen komposit $\mathrm{B}$ dan $\mathrm{C}=106,0461 \mathrm{~N}$. sedangkan genteng komersil $\mathrm{A}=150,2892 \mathrm{~N}$, spesimen genteng komersil $\mathrm{B}=159,1182 \mathrm{~N}$.
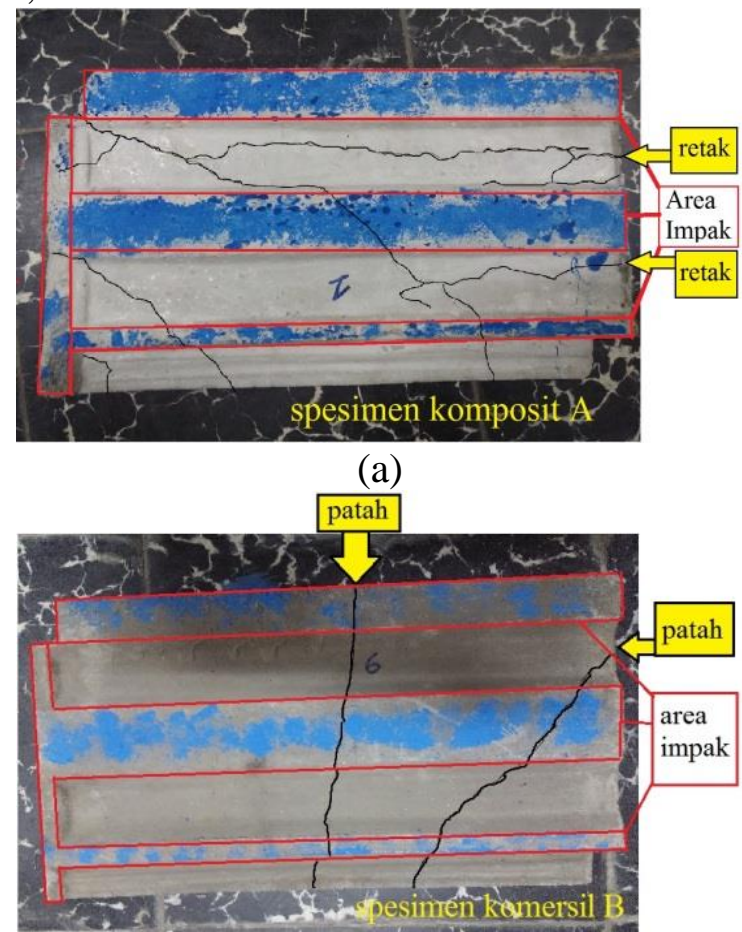

(b)

Gambar 4.6 Pola kerusakan spesimen (a) komposit (b) komersil. Ketinggian 0,5 m.

Berdasarkan pola kerusakan yang ditunjukkan pada Gambar 4.6. spesimen genteng komposit mengalami retak pada bagian tengah diakibatkan struktur genteng yang berserat sehingga gaya impak yang diserap oleh genteng tersebut tidak terdistribusi dengan baik, selain genteng komposit juga mengalami patah matriks dengan kedalaman patahan hingga $5 \mathrm{~mm}$. Sedangkan 
pada spesimen genteng komersil, stuktur genteng yang padat, kuat dan keras membuat gaya impak yang diterima lebih besar dan mengakibatkan patah.

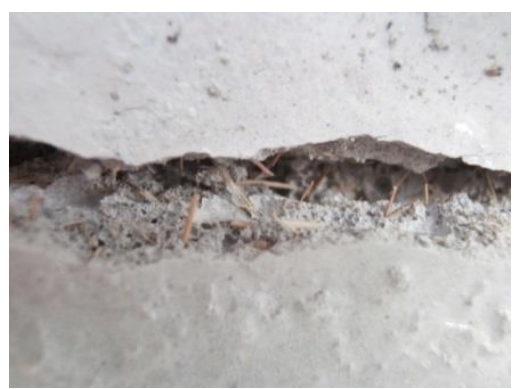

(a)

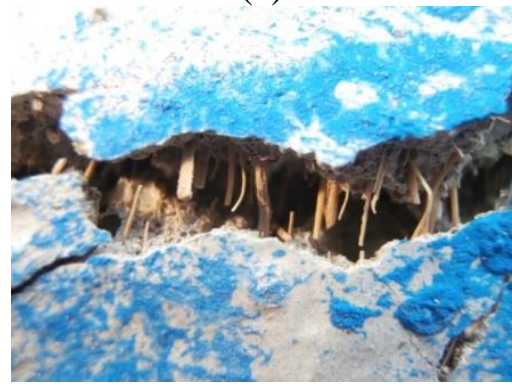

(b)

Gambar 4.7 Patahan pada area impak ketinggian 0,5 m (a) secara tidak langsung, (b) secara langsung

Pada Gambar 4.7 (b) dapat dilihat retakan pada area titik tengah area impak terdapat banyak fiber yang meredam sebagian gelombang impak yang diterima sehingga kegagalan yang terjadi pada matriks tidak total dan serat belum mengalami kegagalan. Pada Gambar 4.7 (a) distribusi serat masih kurang merata dibanding dengan Gambar 4.7 (b).

2. Ketinggian $1 \mathrm{~m}$

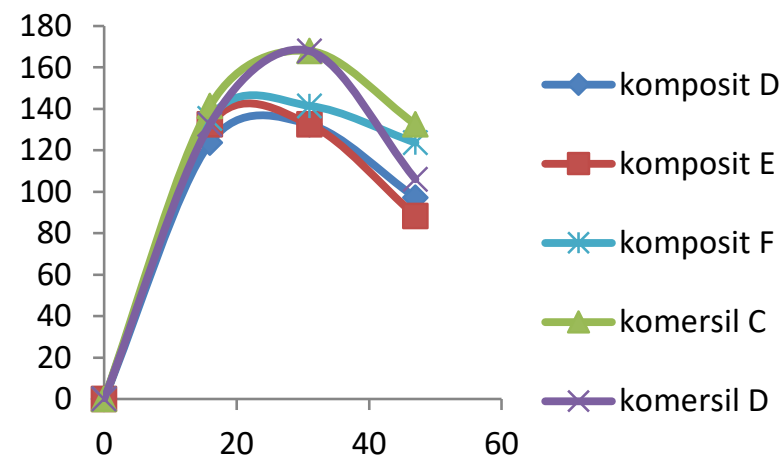

Gambar 4.8 Grafik gaya impak ketinggian jatuh $1 \mathrm{~m}$.

Dari Gambar 4.8 dapat dilihat bahwa untuk kategori gaya impak ketinggian $1 \mathrm{~m}$ untuk genteng komposit diperoleh gaya impak spesimen komposit $\mathrm{D}$ dan $\mathrm{E}=132,5331 \mathrm{~N}$, spesimen komposit $\mathrm{F}=141,4602 \mathrm{~N}$. sedangkan genteng komersil $\mathrm{C}$ dan $\mathrm{D}=167,9472 \mathrm{~N}$. 
Pada grafik gaya impak yang ditunjukkan Gambar 4.8 genteng komersil menerima gaya impak 80,68\% lebih besar dari genteng komposit pada ketinggian $1 \mathrm{~m}$.

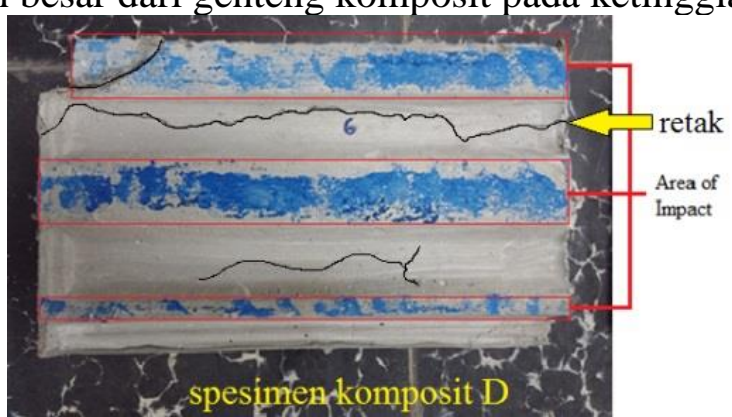

(a)

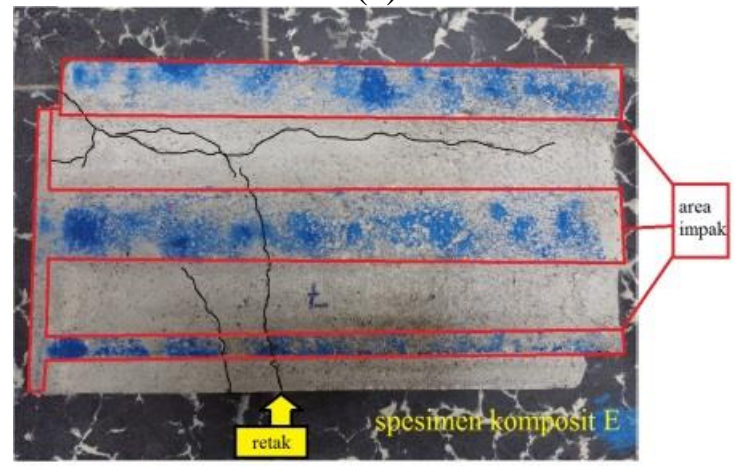

(b)

Gambar 4.9 Pola kerusakan spesimen (a) komposit (b) komersil, ketinggian $1 \mathrm{~m}$.

Berdasarkan pola kerusakan yang ditunjukkan pada gambar 4.9. spesimen genteng komposit mengalami retak pada bagian tengah diakibatkan struktur genteng yang berserat sehingga gaya impak yang diserap oleh genteng tersebut tidak terdistribusi dengan baik. Pada ketinggian $1 \mathrm{~m}$ genteng komposit mengalami kegagalan pada matriks dengan kedalaman patahan hingga $15 \mathrm{~mm}$ sesuai dengan tebal genteng tersebut, namun belum mengalami kegagalan pada serat. Sedangkan pada spesimen genteng komersil, stuktur genteng yang padat, kuat dan getas membuat gaya impak yang diterima lebih besar dan mengakibatkan patah.

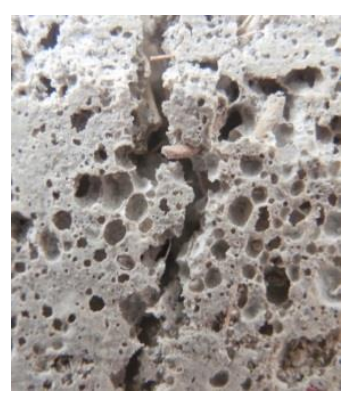

(a) 


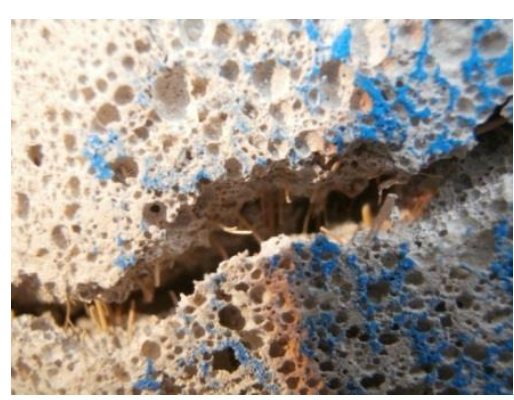

(b)

Gambar 4.10 Patahan pada area impak ketinggian $1 \mathrm{~m}$ (a) secara tidak langsung, (b) secara langsung.

Bentuk patahan pada specimen komposit dapat dilihat pada gambar dimana pada area impak specimen terlihat bahwa terjadi kegagalan pada matriks namun serat masih belum mengalami kegagalan sehingga spesimen tidak langsung putus. Distribusi serat pada gambar 4.10 (a) yang merupakan bagian samping dari spesimen terlihat kurang merata dimana bagian tengah spesimen memiliki lebih banyak serat.

\begin{tabular}{cccc}
\hline Spesimen & $\begin{array}{c}\text { Ketinggi } \\
\text { an }(\mathbf{m})\end{array}$ & $\begin{array}{c}\text { Teganga } \\
\mathbf{n}(\mathbf{M P a})\end{array}$ & $\begin{array}{c}\text { Kondisi } \\
\text { Spesime } \\
\mathbf{n}\end{array}$ \\
\hline $\begin{array}{c}\text { Komposit } \\
\text { A }\end{array}$ & 0,5 & 0,00026 & retak \\
$\begin{array}{c}\text { Komposit } \\
\text { B }\end{array}$ & 0,5 & 0,00028 & retak \\
$\begin{array}{c}\text { Komposit } \\
\text { C }\end{array}$ & 0,5 & 0,00028 & retak \\
$\begin{array}{c}\text { Komersil } \\
\text { A }\end{array}$ & 0,5 & 0,00039 & patah \\
$\begin{array}{c}\text { Komersil } \\
\text { B }\end{array}$ & 0,5 & 0,00042 & patah \\
$\begin{array}{c}\text { Komposit } \\
\text { D }\end{array}$ & 1 & 0,00035 & retak \\
$\begin{array}{c}\text { Komposit } \\
\text { E }\end{array}$ & 1 & 0,00035 & retak \\
$\begin{array}{c}\text { Komposit } \\
\text { F }\end{array}$ & 1 & 0,00037 & retak \\
$\begin{array}{c}\text { Komersil } \\
\text { C }\end{array}$ & 1 & 0,00044 & patah \\
Komersil & 1 & 0,00044 & patah \\
D & & &
\end{tabular}

\section{Kesimpulan dan Saran}

Kesimpulan

1. Analisa hasil produk genteng komposit berbahan concrete foam diperkuat serat TKKS berdasarkan kualitas fisik:

a. Reduksi berat 
Berat genteng komposit berbahan concrete foam diperkuat serat TKKS berhasil direduksi hingga $44,89 \%$ dan memiliki berat rata-rata $1,518 \mathrm{~kg}$.

b. Makrostruktur

Porositas yang terjadi pada permukaan genteng komposit $=49,42 \%$ per $100 \mathrm{~mm}^{2}$ dengan besar butir rata-rata $=0,008 \mathrm{~mm}^{2}$ dan pada potongan bagian dalam $=62,3 \%$ per $100 \mathrm{~mm}^{2}$ dengan besar butir rata-rata $=0,013 \mathrm{~mm}^{2}$. Maka, rata-rata area porositas pada spesimen genteng komposit $=55,86 \%$.

c. Rembesan air

Dari hasil uji permeabilitas genteng dengan jumlah sampel sebanyak 3 buah yang sudah dilapisi dengan cat beton, diperoleh bahwa genteng dari bahan komposit concrete foam diperkuat serat TKKS mampu menahan kuantitas air selama 20 jam \pm 5 menit tanpa adanya kerusakan struktur dan rembesan air. Meskipun tidak terjadi rembesan air namun genteng menjadi lembab akibat penyerapan air hingga $62 \%$ yang diakibatkan oleh porositas yang cukup tinggi pada spesimen.

2. Hasil pengujian pada genteng komposit ketinggian $0,5 \mathrm{~m}$ Fmax $=106,0461 \mathrm{~N}$, Tegangan $=$ $0,00028 \mathrm{MPa}$ dan pada genteng komersil; Fmax = 159,1182 N , Tegangan =0,00042 MPa. Sedangkan pada ketinggian $1 \mathrm{~m}$ untuk genteng komposit; Fmax $=141,4602 \mathrm{~N}$, Tegangan $0,00037 \mathrm{MPa}$ dan pada genteng komersil;; Fmax $=167,9472 \mathrm{~N}$, Tegangan $=0,00044 \mathrm{MPa}$. Kondisi spesimen pada genteng komposit pada ketinggian 0,5 m dan $1 \mathrm{~m}$ adalah patah pada matriks dan belum patah serat, sedangkan pada genteng komersil pada ketinggian 0,5 $\mathrm{m}$ dan 1 $\mathrm{m}$ genteng mengalami patah matriks dan terpisah menjadi beberapa bagian.

3. Perbedaan pola kerusakan pada genteng komposit dan komersil disebabkan pada genteng komposit sifat fisisnya berubah menjadi kurang getas dan juga pengaruh serat TKKS sehingga tegangan yang masuk pada spesimen dapat diredam sebagian dan tidak langsung mengakibatkan patah. Sedangkan pada genteng komersil, struktur yang padat, kuat namun getas mengakibatkan spesimen langsung patah ketika dikenai tegangan.

\section{Saran}

1. Dalam pembuatan spesimen perlu ada ide-ide agar spesimen tidak rusak sewaktu dibuka dari cetakan.

2 Pembuatan genteng komposit berbahan concrete foam dengan penguat serat TKKS diharapkan dapat menjadi acuan dan ide baru dalam menghasilkan berbagai macam produk lain dengan bahan concrete foam.

3. Diperlukan penelitian lebih lanjut untuk coating pada genteng agar penyerapan airnya dapat dikurangi.

4. Diperlukan penelitian lebih lanjut untuk variasi butir pasir agar dapat mengurangi porositas yang tidak diinginkan pada genteng komposit.

\section{Penghargaan}

Pada kesempatan ini penulis mengucapkan penghargaan dan rasa terima kasih kepada Bapak Prof. Dr. Ir. Bustami Syam, MSME. (selaku dosen pembimbing; Proyek hibah MP3EI; dan tidak lupa juga kepada seluruh Tim Lab. IFRC USU, atas sarana dan fasilitas pengujian, serta rekan-rekan mahasiswa baik langsung maupun tidak yang telah membantu penyelesaian studi S1 saya ini. 


\section{DAFTAR PUSTAKA}

[1]. Isroi, Pengolahan TKKS (Tandan Kelapa Sawit), (Online) http://isroi.wordpress.com/, diakses tanggal 4 Juli 2014, pukul 13:32 WIB.

[2]. Yoppy Anggoro, Makalah Ilmu Bahan I Beton, Fakultas Teknik Universitas Sultan Ageng Tirtayasa, Cilegon, Banten, 2008.

[3]. Nuzuli Fitriadi, Penyelidikan Perilaku Mekanik Material Concrete Foam Diperkuat Serat TKKS Terhadap Beban Statik Dan Impak. 2014. Tesis pada Magister Teknik Mesin USU Medan: tidak diterbitkan.

[4]. Siswo Pranoto, Desain Dan Pembuatan Kerucut Lalu Lintas Dari Bahan Polymeric Foam Diperkuat Serat Tandan Kosong Kelapa Sawit (TKKS), 2010. Tesis pada Magister Teknik Mesin USU Medan: tidak diterbitkan.

[5]. Dorel Feldman, Bahan Polimer Konstruksi Bangunan, Gramedia Pustaka Utama, Jakarta, 1995.

[6]. Wikipedia, Material Komposit, (Online) http://id.wikipedia.org/wiki/Material_komposit tanggal akses 22 Oktober 2014, pukul 15.33 WIB.

[7]. Krishan Kumar Chawla, Composite Materials, Springer New York, New York, 1987.

[8]. SNI 03-6817-2002, Metode Pengujian Mutu Air Untuk Digunakan Dalam Beton, (Online) http//sisni.bsn.go.id/ tanggal akses 15 Oktober 2014, pukul $15.30 \mathrm{WIB}$.

[9]. SNI 0096-2007, Genteng Beton, (Online) http://sisni.bsn.go.id/ tanggal akses 15 Oktober 2014, pukul 14:40 WIB. 